УДК 788.1(497.11)(049.3)

https://doi.org/10.55302/MF2179071j

Jelena Jokovich

\title{
INTERSTYLISTIC NETWORKING OF TRUMPET ORCHESTRAS OF WESTERN, NORTHEASTERN AND SOUTHEASTERN SERBIA ON THE EXAMPLE OF PERFORMING THE MELODY OF "PSHENICHICE, SITNO SEME"1 SONG ${ }^{2}$
}

\begin{abstract}
Contemporary trumpeting in Serbia is very heterogeneous and hybrid in terms of repertoire. Trumpet orchestras, in addition to songs (melodies of folk songs and kolo/chochek ${ }^{3}$ dances) originating from the region where they come from, also perform a repertoire of other Serbian trumpeting styles. In methodological terms, this paper deals with multiethnic, interstylistic networking, and individual performance characteristics of trumpeters on the example of performing the melody of "Pshenichice, sitno seme" song and the role of different media through its transmission. This song is one of the very popular songs in the world of trumpet music in Serbia, but over time, it has crossed Serbian borders. It is often performed at the Dragachevo Trumpet Festival in Gucha as a competition song, both in senior and junior groups, and it was also recorded many times on analog sound carriers, which, with the advent of the Internet, have been digitized and become more accessible. The ethnomusicological analysis consists of a comparison of three exemplary performances of "Pshenichice, sitno seme" (performed by trumpeter Miroslav Matushich, the orchestras of Svetozar Lazovich Gongo and Boban Markovich). The main musical elements of the comparison of the three performances by the mentioned trumpet giants are melodic-rhythmic characteristics, ornamentation, articulation, and performing tone. These three trumpeters are role models for the middle and younger generations of trumpeters from all three "trumpeting" regions of Serbia. In different interpretations, they network the performances by the mentioned trumpet role models, the stylistic features of the trumpeting centers where young trumpeters come from, but also by giving a personal stamp.
\end{abstract}

Keywords: multiculturalism, interculturalism, trumpet performing styles of Serbia, individualism in interpretation, "Pshenichice, sitno seme".

The motive for studying this topic came from a longer observation of the developmental tendencies of modern Serbian trumpeting, but with a special focus on the brass orchestras of western Serbia. The fact is that today's trumpeting in Serbia is very heterogeneous and hybrid in terms of repertoire and performance style. This tendency has been going on for several decades, which is especially reflected in the trumpet orchestras of western Serbia and some of its very significant representatives, such as Svetozar Lazovich Gongo from Jezhevica near Pozhega (1952-2001), Radojko Vitezovich from Tubichi near Kosjerich (1952), Boshko

${ }^{1}$ Translator's note: the author addresses wheat using hypocorism, referring to wheat as tiny seeds.

2 The article was written within the Music and Dance Tradition of Multiethnic and Multicultural Serbia project (No. 177024) of the Ministry of Education, Science and Technological Development of the Republic of Serbia.

${ }^{3}$ Translator's note: a musical genre and dance that emerged in the Balkans during the early 19 th century. 
Ostojich from Zlakusa near Uzhice (1937), Milovan Micho Petrovich from Duboko near Uzhice (1961-2000) and many others, and the trend continues with their successors. In terms of repertoire, this trend can be seen in the performances of chochek and Vlach kolo dances, as well as in the composition of melodies for kolo dances and songs in the Vlach style and chochek manner. ${ }^{4}$

On the other hand, there are kolo dances and songs that were performed by trumpeters and their orchestras equally in all three trumpet styles. One of those songs is the traditional song "Pshenichice, sitno seme". This song is one of the most popular in the world of folk trumpet music of Serbia. It should be noted that folk music singer Predrag Cune Gojkovich $(1932$ - 2017) was one of the first (if not the first) to record this song in $1965,{ }^{5}$ and it was often recorded by accordionists, such as Radojka Zhivkovich (1923 - 2002), ${ }^{6}$ Jovica Petkovich $\left(1927\right.$ - 2015), ${ }^{7}$ Ljubisha Pavkovich $(1947)^{8}$ and others.

As for the trumpet performance of this song, the first to record it was the Vlach musician of Roma origin Miroslav Matushich (1925 - 1991) from Kuchevo, afterward it was popularized in western Serbia by trumpet player Svetozar Lazovich Gongo. He popularized this beautiful song even more, and the song popularized him. This song was also performed and recorded by trumpeters and their orchestras in southeastern Serbia, such as Nenad Mladenovich (1970), Boban Markovich (1964), and others.

It was often performed at the Dragachevo Trumpet Festival in Gucha as a competition song, both in senior and junior groups, considering that, in addition to its melody sounding nice, it is technically (melodically-rhythmically and ornamentally) also very demanding, and the trumpet who is able to perform it well, mostly wins the audience, but also the expert jury. ${ }^{9}$

This paper aims to present unity, but also individuality in multiethnic and stylistic-performing diversity, as well as their causes, through the influence of cooperation of trumpeters of different trumpet performing styles, Dragachevo

4 Listen to the recording Svetozar Lazovich „Draganovo kolo“ https://www.youtube.com/watch?v=O0rccnhvpbQ [Accessed 20.9.2020].

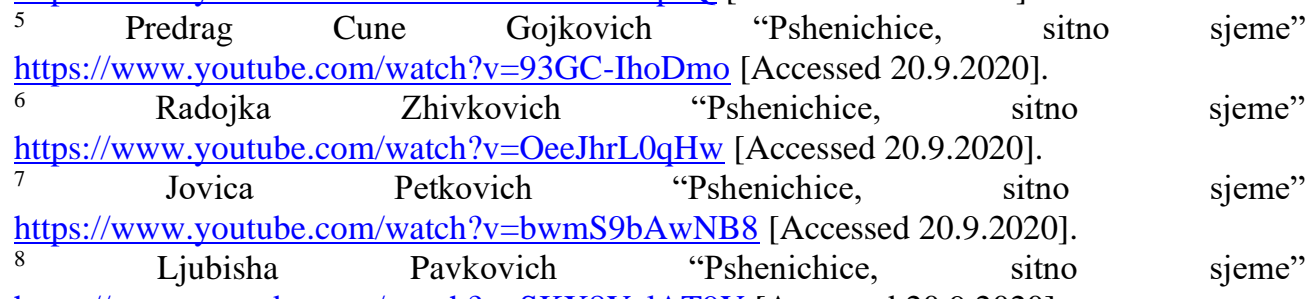

https://www.youtube.com/watch?v=SKX8YclAT9Y [Accessed 20.9.2020].

${ }^{9}$ The first to perform this song at the Dragachevo Trumpet Festival was Svetozar Lazovich Gongo with his orchestra in 1985, and 1992, he was awarded by jury as the best trumpeter of Festival. Then, in 1986, Nenad Mladenovich, as the first trumpeter in the orchestra of his father Milan Mladenovich (formerly Ekrem Mamutovich), performed this song and was proclaimed the best trumpeter of the Festival. Dalibor Lukich from Zajechar performed this melody in 1996 and was named the best trumpeter of the pre-competition in Boljevac. In 1998, Boban Markovich won the "First Trumpeter" award, also with this song. In 2004, Veljko Ostojich was also the best trumpeter of the Festival. 
Trumpet Festival as a living medium, and various recorded analog and digital sound carriers (gramophone records, tapes, CDs, internet).

According to Timothy Rice's classification, this paper is a local, idiographic study divided into two dimensions: the first, which represents the types of communities in geographical and ethnic terms, and the second, which sheds light on ethnomusicological themes related to music and identity, as well as teaching and learning music (Rice, 2010, 109).

Namely, the first dimension fits into this work musically and geographically, as the representatives of three geographical regions of Serbia (west, northeast, and southeast) are given as examples, while, in ethnic terms, three ethnicities would be considered: Serbs, Vlach Roma from northeastern Serbia and Roma from southeastern Serbia.

Within the second dimension, as given above, this study talks about the interaction of music and identity (in this case, the interaction of ethnic and traditional musical identity). Then, an important factor is the process of transmission, which takes place between teaching and learning to perform a certain melody by listening to a live performance or its recording from various sound carriers and repetitions (imitation or variant). The main role in this type of learning is played by memorizing the sound, considering there is no musical notation, and even if there was, most trumpeters cannot read musical notations.

In methodological terms, the paper deals with multiethnic, interstylistic networking and individual performance characteristics of trumpeters who performed "Pshenichice, sitno seme" song, as well as the role of different types of media in transmitting this song among trumpet orchestras.

According to ethnomusicologists Danka Lajich-Mihajlovich and Mirjana Zakich, "at the turn of the century, when trumpeting in Serbia was in its infancy, the dialectal features of traditional music in rural areas were clearly differentiated, so the trumpet was 'grafted' on different surfaces. Also, part of the trumpet music dialects peculiarity comes from the ethnic profile of orchestras - Serbian in the western parts, Roma in the southeast, as well as a specific mosaic of Serbian, Vlach and Roma idioms in the (north) east"10 (Lajich-Mihajlovich, Zakich, 2012, 227228).

The ethnomusicological analysis consists of two parts: the first, a comparison of the three main performances of "Pshenichice, sitno seme" song (performed by trumpeter Miroslav Matushich from 1975, ${ }^{11}$ the orchestra of Svetozar Lazovich

10 As a proof for this claim, in the paper entitled Similarities and differences in the performing style of trumpet orchestras of western, northeastern and southeastern Serbia, on the example of performing 'Moravac', presented at the scientific gathering "Tradition as Inspiration" within the "Vlada S. Miloshevich Day" in Banja Luka in 2019, I showed, on the example of performing the "Moravac" kolo dance melody, how trumpet orchestras from western, northeastern and southeastern Serbia "graft" using their characteristic stylistic determinants (ornamentation and articulation) on the melodic-rhythmic basis of this kolo dance, as invariant constants.

${ }^{11}$ Miroslav Matushich (1925-1991) was born in the village of Brodica, between Kuchevo and Majdanpek, as a Vlach Roma. He started playing the trumpet with local musicians when he was less than seven years old. He played the trumpet in $\mathrm{C}$, unusual in that, instead of the 
Gongo ${ }^{12}$ from 1984 and Boban Markovich ${ }^{13}$ from 1998) by the following elements: musical form, orchestration, sequence, melody and cadence, harmony and cadence, rhythm and cadence, ornamentation, articulation, trumpet and the whole orchestra timbre. The paper will present transcriptions of three complete performances (which will be attached to the paper).

The second part of the analysis consists of comparing later recordings of performances by younger trumpeters and their orchestras from three trumpet centers, but those modeled after exemplary performances of new trumpeters who are not close to their trumpet performing style (Veljko Ostojich, Janko Jovanovich, Ivan Papich, and Ivan Kadrich). In that way, the level of the hybridization process

standard three, it had four piston valves, so he could play certain decorative tones with his little finger. He was a trumpeter of "minor scale and minor elegiac melody...". They played at village kermises, slavas, weddings and memorial services. Over time, Matushich grew into an excellent and well-known trumpet player. He played with the trumpet orchestra until 1956/57, when he became independent. The orchestra composition was as follows: trumpets, clarinet, saxophone, two tenor horns, trombone, double bass, drum and small drum. Later, he collaborated in Belgrade with the orchestra of famous accordionist Miodrag Mija Krnjevac. In mid seventies of the last century he recorded the album for "Jugodisk" entitled A Medley of selected songs on trumpet by Miroslav Matushich, which includes the performance of "Pshenichice, sitno seme". He died in Pozharevac in 1991 (Бабић, 2002, 193-205). Miroslav Matushich "Pshenichice, sitno seme" https://www.youtube.com/watch?v=xFkGkdAXaXQ [Accessed 20.9.2020].

${ }_{12}$ The wind orchestra of Svetozar Lazovich Gongo from Jezhevica near Pozhega, with conductor Svetozar Lazovich Gongo, was formed in 1978 as a continuation of the orchestra conducted by trumpeter Radovan Babich until his death in 1979. Lazovich's trumpet role model was Vlach trumpeter Miroslav Matushich. He won all the most important awards at the Dragachevo Trumpet Festival in Gucha, and was awarded the Master Letter in 1994, as a three-time winner of the First Trumpet and Best Orchestra awards. He was once considered an extraordinarily talented trumpeter. He was mostly self-taught. He also collaborated with trumpeter Ajdin Ajdinovich (Бабић, 2002, 144-145). Svetozar Lazovich Gongo "Pshenichice, sitno seme" https://www.youtube.com/watch?v=GixOzfvU7ME [Accessed 20.9.2020].

${ }^{13}$ Boban Markovich (1964) was born in Vladichin Han, and at the age of sixteen he began his professional engagement in music. He founded his orchestra at the age of 20, and then he started competing at the Festival in Gucha. Markovich competed at that festival for the first time in 1986, and won the "Golden Trumpet" for the first time in 1988. Since then, he has won the same award five more times, ending in 2001, when he last participated in the festival. He received the award for the best trumpet player (Trumpet Master) in 1995, as the highest recognition a wind instrument musician can receive in the Balkans. Boban Markovich https://sr.wikipedia.org/wiki/Boban_Marković [Accessed 20.9.2020]. In late eighties, he entered the trumpet stage of Serbia. He started playing the trumpet when he was seven. He was first a member of Junuz Ismailovich's orchestra. His orchestra was the best in 1993 and 2000, he was named the best trumpet player in 1988, 1991, 1998 and 2001, and he won the best trumpet by audience award in 1994. He is ranked among the world music performers (Slavkovich, 2007, 103). Boban Markovich "Pshenichice, sitno seme" https://www.youtube.com/watch?v=13XcHd5W4RY [Accessed 20.9.2020]. 
would be seen, which was supported by the media commercialization and physical networking of the trumpeters of these three trumpet centers.

When analyzing the individual characteristics of individual performances, I will rely on the published article by Igor Vladimirovich Matsiyevsky (Мацієвський Ігор Володимирович) on the performing nature and artistic text in "ethnic" music and concepts such as performance, ${ }^{14}$ improvisation, ${ }^{15}$ and interpretation ${ }^{16}$ (Matsiyevsky, 2014, 17-18). This primarily refers to the following musical elements: melody, rhythm, ornamentation, articulation, and timbre. When it comes to the concept of improvisation, in the interpretation by a trumpeter it is predominantly prepared and learned and not completely spontaneous, which is its basic feature, though, in the formal sense, it still is.

Given that the transmission of folk melodies is done orally, by direct learning from exemplary performers or audio recording, and not from sheet music, the question arises as to how much "sound" text differs from live, personal performance, which Igor Matsiyevsky and Monique Desroches (Desroches, 2008, 103-115) talk about. They emphasize that if the performance of a certain folk melody would reflect a mere imitation of an exemplary played musical text, further interpretations would reflect the hermeticity and one of the basic features of folk music would be lost.

\section{Multi- and interculturalism, musical identity and identities and the role of different media in interstylistic networking}

The Republic of Serbia belongs to the group of multiethnic, multiconfessional, and multicultural countries of the world. In addition to the Serbian people as the majority, there are over twenty national minorities living in Serbia, ${ }^{17}$ of which the most important for this paper are Vlachs (and Vlach Roma) in northeastern Serbia and Roma in southeastern Serbia.

${ }^{14}$ Performance (in the broadest sense) - a live presentation of a piece of music to the listener by a singer or (and) instrumentalist; in a narrower sense - articulation, realization of an artistic text while singing or playing an instrument, written in musical form by a composer or on a sound carrier from traditional musicians - without any fundamental compositional changes. It is characteristic of European academic music or, sometimes, of the reproductive activity of secondary folk ensembles (Мацијевски, 2007, 17).

${ }^{15}$ Improvisation - the creation of an artistic text of a piece of music in the process of its performance, directly during dancing or singing (Мацијевски, 2007, 17). For more on the concept, types and roles of improvisation, see: Lortat-Jacob, 1987, 274.

${ }^{16}$ Interpretation - a unique way of realizing a composer's text, in which the performer finds his own original ways of phrasing, articulation, its stroke, dynamic and agogic nuances, without disturbing the composer's orientations and without affecting the rhythmic-melodic and compositional structure of the composer's text. It is analogous to the performance of a folklore work, which follows a (musical) transcription or sound recording (Мацијевски, 18).

17 See more on: Srbija https://sr.wikipedia.org/srес/Србија\#Народи_и_националне_мањине [Accessed 20.9.2020]. 
Multiculturalism as a phenomenon has been defined several times so far; however, several explanations by Mladena Prelich stand out as most appropriate for this paper. She defines "multiculturalism" as follows:

"In one sense, it is used as a synonym for ethnic pluralism (multiethnicity) within one state, for tolerating cultural differences, i.e. for a peaceful coexistence of different ethnic groups within one society (i.e. state), but also (often with a negative connotation) in the sense of coexistences of cultures that are closed in on themselves, clearly demarcated, without mutual cultural exchange. In addition, it is used in the meaning quite opposite to clearly demarcated, mutually separated cultures - as a synonym for the processes of cultures and identities hybridization in the modern globalized world. However, in professional and scientific discourse, multiculturalism primarily means a type of public policy, which refers to cultural diversity in a multiethnic society, i.e. the ways in which it should be treated in society and the state. Multiculturalism can be defined as a specific public policy related to cultural differences management in multiethnic societies, which officially emphasizes mutual respect and tolerance for cultural differences within the borders of a state" (Прелић, 2012, 140-141).

In Serbia, during the twentieth century, especially from the sixties, and during the twenty-first century, cultural policies on the issue of multiculturalism and folk traditional culture went through different phases as the general policy changed. This is best reflected in the diachronic view of the cultural and propositional policy of manifestations such as the Dragachevo Trumpet Festival in Gucha since 1963. ${ }^{18}$ It was an interesting phenomenon, within the propositional policy of the Festival, which was visible in the mid-1960s and, in part, in the 1970s, that trumpet orchestras from southeastern Serbia played kolo dance, not chochek, as an obligatory melody, which had a political and cultural background. ${ }^{19}$ In that period, chocheks were not particularly popular, and during the judging, the performances of kolo melodies were valued better than chocheks. The brass orchestra of Junuz Ismailovich from Prekodolac near Vladichin Han was especially famous for this; it often performed and recorded kolo melodies, which sound very reminiscent of those from western Serbia. ${ }^{20}$

In 2008, the Council of Europe adopted a document in Strasbourg, the socalled "White Paper on Intercultural Dialogues", with the motto "Living together as equals in dignity", to which the Republic of Serbia is a signatory. According to this document, "intercultural dialogue is understood as an open and respectful exchange of views between individuals, groups with different ethnic, cultural, religious and linguistic backgrounds and heritage on the basis of mutual understanding and

${ }^{18}$ See more in: Timotijevich, 2005.

${ }^{19}$ At that time, chocheks were not particularly popular, so the propositional policy of the Dragachevo Festival valued the performance of kolo melodies better than chochek, because "kolo" dance, and not chochek, represented the Serbian (and Yugoslav) identity.

${ }^{20}$ Junuz Ismailovich "Klisursko kolo" https://www.youtube.com/watch?v=usrLvzXeiBU, Junuz Ismailovich "Vrlolechko kolo" followed by the Youtube link https://www.youtube.com/watch?v=8WvqqlE9Ons, Trumpet orchestra by Junuz Ismailovich - "Dragachevka" https://www.youtube.com/watch?v=sNOAl-d3Ayo [Accessed 20.9.2020]. 
respect". ${ }^{21}$ It seeks to more deeply develop attitudes towards different views and practices in the world, to increase cooperation and participation (or the freedom to make choices), to strengthen the development and transformation of the individual, and to promote mutual tolerance and respect. ${ }^{22}$ The European Court of Human Rights considers that pluralism constitutes "genuine recognition of, and respect for, diversity and the dynamics of cultural traditions, ethnic and cultural identities, religious beliefs, artistic, literary and socio-economic ideas, and concepts", and that "harmonious interaction of persons and groups with varied identities is essential for achieving social cohesion". ${ }^{23}$ Intercultural dialogue is a mechanism for harmonizing identities, for a new beginning and new experiences, which adds new features of identity, without renouncing one's own origin.

The beginnings of intercultural dialogues at the Festival could be seen from 1963 when the representatives of three ethnic and musical-stylistic identities appeared for the first time: Serbian, Roma, and Vlach, to 2019, in the national ${ }^{24}$ and international competition segment, ${ }^{25}$ as well as in the non-competition part called "Moonlight" Midnight Concert. ${ }^{26}$ In all the above-mentioned segments of the event, trumpet orchestras from western, southeastern, and northeastern Serbia networked and conducted dialogues in style and repertoire (this is especially evident at the Midnight Concert). Outside the Festival, intercultural dialogues between trumpeters and trumpet orchestras take place by mixing members of different orchestras from different parts and musical trumpet dialects of Serbia, all the way to joint playing and mutual taking of songs (especially when it comes to chocheks). Thus, there are known cases of joint gigs by Svetozar Lazovich Gongo from Pozheshka Jezhevica with Miroslav Matushich from Kuchevo in northeastern Serbia and Ajdin Ajdinovich from Surdulica, Milovan Petrovich from Duboko near Uzhice and Osman Salijevich (father of trumpeter Slobodan Salijevich) and the like. ${ }^{27}$

${ }^{21}$ For more information, see:

https://www.coe.int/t/dg4/intercultural/Source/Pub_White_Paper/WhitePaper_ID_SerbianV ersion.pdf, 7 [Accessed: 20/9/2020].

${ }^{22}$ More on intercultural dialogues in: https://www.coe.int/t/dg4/intercultural/Source/Pub_White_Paper/WhitePaper_ID_SerbianV ersion.pdf, 11.

${ }^{23}$ For more information, see: https://www.coe.int/t/dg4/intercultural/Source/Pub_White_Paper/WhitePaper_ID_SerbianV ersion.pdf, 8.

${ }^{24}$ See more about the national trumpet competition in Gucha in: Zakich, Lajich Mihajlovich, 2012, 58-79.

25 See more about the international trumpet competition in Gucha in: Закић, ЛајићМихајловић, 2014, 299-308. Dzambo Agushev (North Macedonia) performed this song with own trumpet orchestra and won in 2011. "Dzambo Agushevi Orchestra (Macedonija) Gucha 2011 - International Contest" https://www.youtube.com/watch?v=Lyvq9mDtgNI [Accessed 20.9.2020].

${ }^{26}$ See more on the "Moonlight" Midnight Concert in: Lajich Mihajlovich, Zakich, 2012, 223-236; Lajich Mihajlovich, 2013, 18-31.

27 Milovan Micha Petrovich \& Osman i Slobodan Salijevich 1993 https://www.youtube.com/watch?v=5N4cL0Bj-p4 [Accessed 20.9.2020]. 
In terms of identity, Laurent Aubert views it on two levels: the collective (objective), which includes, among other things, ethnic affiliation, and the individual (subjective) (Aubert, 2007, 11). Collective (musical) identity, within this paper, represents a set of three different ethnic and musical-stylistic identities: Serbian, Vlach, and Roma identity, within one multicultural society, on the example of three performances of the same song. ${ }^{28}$ Individual (musical) identity, on the other hand, is an interpretive personal stamp, in constellation with musical elements, which represent collective identity on the performing level. ${ }^{29}$

According to Douglas Kelner, "media culture provides the materials to create identities whereby individuals insert themselves into contemporary technocapitalist societies" (Kelner, 2004, 5). Media culture consists of, among other things, systems of radio and the reproduction of sound (Kelner, 2004, 5). According to Owe Ronstrom, this definition would fall under the category of "media arenas", as opposed to "live arenas", which involve live performances, such as performances at events such as the Dragachevo Trumpet Festival in Gucha (Lundberg, Kristen, Ronström, 2003, 53-61). Media arenas in the form of sound carriers, such as tracks on gramophone records, tapes, and somewhat later compact discs, have been digitally transferred to the Internet and sites such as YouTube in modern times (Lundberg, Kristen, Ronström, 2003, 335-353). Thus, in the Socialist Federal Republic of Yugoslavia, the first trumpeter to record an album in 1963 was Radovan Babich (1922 - 1979) from Milichevo Selo near Pozhega. ${ }^{30}$ However, in the seventies, and especially in the eighties and nineties, trumpeters began to record albums for the then famous music houses, such as Zagreb's "Jugoton", Belgrade's Radio Belgrade, "Jugodisk", "Diskos" and many others. For "Jugodisk", for example, in the middle of the seventies of the last century, Miroslav Matushich made a gramophone record A Medley of selected songs on trumpet by Miroslav Matushich, which included the performance of "Pshenichice, sitno seme". ${ }^{31}$ With the advent of sound carriers, interstylistic networking has become simpler and more accessible, and repertoire heterogenization and musical-stylistic hybridization have become increasingly common in contemporary Serbian trumpeting.

\section{Ethnomusicological analysis of three exemplary performances}

In general, in terms of form, this song mainly consists of five macroformal wholes, which are very often repeated once more after the presentation. It is performed in a rubato rhythmic system. The orchestration in all performances, regardless of the performing orchestra (except when it comes to the performance by Miroslav Matushich), consists of a solo section of the first trumpet, with a characteristic performance of the second and third (in the segment when playing a sequence down in thirds). Tenor hornists and bassist (heliconist) perform rhythmic

${ }^{28}$ See more on the collective (group) identity in: Rice, 2007, 22-24.

${ }^{29}$ See more on the individual identity in: Rice, 2007, 22-23.

30 Miroslav Matushich - "Pshenichice, sitno seme" https://www.youtube.com/watch?v=xFkGkdAXaXQ [Accessed 20.9.2020].

31 "Psenicice, sitno seme" https://www.youtube.com/watch?v=j-Aiz9OZUC4 [Accessed 20.9.2020]. 
shifts of harmonies, following the performance of the first trumpeter melody, regardless of the specific rhythm, while the drummer follows the harmonic instruments and usually marks changes of harmonies. Melodic cadences generally end in the second and first degree of the above tonalities, while, harmonically, they would be interpreted as a pause on the dominant and tonic chord.

Musical parameters that are potential stylistic determinants are the following: ornamentation, articulation, and tone color, while personal interpretive characteristics could include, in addition to the previous three: creation and variation of melody and rhythm based on the existing melodic-rhythmic base, as well as the existence of improvisational passages.

\subsection{Tonality and melodic-rhythmic characteristics}

The basic tonality, performed by Miroslav Matushich, is in written and sound $\mathrm{c}$ minor, considering that, as mentioned earlier, Matushich played the trumpet in $\mathrm{C}$. Svetozar Lazovich Gongo performed it in a minor trumpet i.e. written tonality, and sound g minor, while with Boban Markovich it is written b minor, and sound a-flat minor.

Comparing the musical images of the first two trumpeters (Miroslav Matushich and Svetozar Lazovich), Svetozar Lazovich played the melody in a way similar to that of Miroslav Matushich, with some added tones and, sometimes, in a rhythmically simpler way. This is an indication that Lazovich did not try to imitate Matushich's interpretation, given the fact that he was his trumpet role model, but relied heavily on it. On the other hand, in terms of melody, Boban Markovich's performance differs from the previous two in that it is somewhat richer, some tones, especially chromatic ones, as well as passages were added. Such a dose of individuality in Markovich's performance is not unexpected, considering that Roma music is more independent and virtuosic, and he himself as a trumpeter is just like that.

\subsection{Ornamentation}

Miroslav Matushich used pralltrillers, mordents, lower and upper acciaccaturas, and combinations of mordent and appoggiatura and mordent, acciaccatura and appoggiatura, as well as a trill in place of a long rhythmic note at the beginning of the second and fourth macroformal segments. He performed vibrato on long note values.

The same type of ornamentation, only in different places, except for the specific ones such as trill, was used by Svetozar Lazovich. He mainly used mordents, pralltrillers, and single upper acciaccaturas in combination with mordent, trill in a characteristic place, double and triple lower acciaccaturas, and appoggiatura. He also used vibrato on long note values.

Boban Markovich performed single and double pralltrillers, single lower and upper and double acciaccaturas, combinations of acciaccaturas with pralltrillers or mordents, as well as a trill in a characteristic place. 


\subsection{Articulation}

As for articulation, Miroslav Matushich mainly used non legato, which he performed by tongue strike using the consonant $\mathrm{D}$, even legato with smaller note values, in a way similar to that of Svetozar Lazovich and Boban Markovich, who used non legato dominantly on the consonant between $\mathrm{D}$ and $\mathrm{T}$, and legato much more rarely. In the third and fifth macroformal segments, Lazovich used tenuto when performing the lowest tone in the melody, $\mathrm{d}^{1}$ followed by a third leap upwards.

\subsection{Timbre}

The color of Matushich's performing tone is fuller, bordering shrillness (considering that its tuning is in C), which is, in general, characteristic of the trumpeters of northeastern Serbia and Vlach instrumental and vocal music in general.

On the other hand, the tone color of Svetozar Lazovich and Boban Markovich and their orchestras is somewhat sharper, and with Markovich it is even more penetrating. Such performance timbres are more or less specific for trumpet playing (and folk music in general) in western and southeastern Serbia.

\section{Analysis of middle and younger generation orchestras performances}

The previously analyzed three trumpeters are mostly taken as role models for the middle and younger generations of trumpeters, who, listening to recordings of their performances, try to perform in the way they performed, but adapting (or perhaps not?!) to their own level of performing technique and musicality.

Thus, Veljko Ostojich (1985), a trumpeter from the Uzhice village of Zlakusa and the grandson of famous trumpeter Boshko Ostojich, whose trumpet orchestra Veljko inherited, performed this song in a more virtuosic way, at a faster pace, since he performed it at Dragachevo Trumpet Festival in Gucha in 2004. ${ }^{32}$ It is characterized by slightly more passages, less ornamental variety, and frequency (he mainly used pralltrillers, mordents, and combinations of acciaccaturas and appoggiaturas). In terms of articulation, he performed the melody predominantly as non legato, rarely legato, while his timbre was sharper, which is a general characteristic of Ostojich's performance. In general, the interpretation is reminiscent of the performance of two trumpeters: Svetozar Lazovich Gongo and Nenad Mladenovich. ${ }^{33}$

Janko Jovanovich (1991), a trumpeter born in Zemun, and from the Uzhice village of Karan by his father, won the award for the best trumpet player of the 57th Dragachevo Trumpet Festival in 2017 in the Ljubivoje Dikovich Brass Band. On

32 "Trumpet orchestra by Veljko Ostojich - 'Pshenichice, sitno seme"" https://www.youtube.com/watch?v=qwL2grjVPn0 [Accessed: 20.9.2020].

33 "Nenad Mladenovich - 'Pshenichice, sitno seme 1986" https://www.facebook.com/goran.antesevic/videos/10213472036064194 [Accessed: 20.9.2020]. 
that occasion, he performed "Pshenichice, sitno seme" as the competitive folk melody. ${ }^{34}$ Before that, he played this song at the pre-competition on Zlatibor Mountain for the final competition at the Festival in Gucha. In his interpretation, the mix of performances by Svetozar Lazovikj Gongo and, in part, Miroslav Matushich is clearly recognizable. There are no special virtuoso passages and other improvisations in Jovanovich's performance, but tenor hornists and the bassist melodically perform a somewhat freer accompaniment at certain moments (especially at the ends of wholes). The use and frequency of ornamentation are close to that used by Svetozar Lazovich Gongo, at times that of Matushich. The timbre of Jovanovich's performance is softer and with a fuller tone compared to the previously mentioned trumpeters from the Uzhice region, in which he approaches the performance of Miroslav Matushich. The articulation is, under the influence of the performing timbre, softer and more fused, he mainly uses legato and non legato (which is performed on consonant D), and at the moment when the second and third trumpeters perform staccato in thirds.

Although he comes from western Serbia, Ivan Papich (1996) from the brass ensemble of his brother, Nikola Papich from Priboj, performed this song at the Youth Competition of the Trumpet Festival in Gucha in 2014, ${ }^{35}$ modeled after the performance of Boban Markovich and other mentioned Roma trumpeters (Elvis Ajdinovich ${ }^{36}$ and Sasha Krstich), ${ }^{37}$ adapting them to own technical and performing abilities. He performed it much more freely, with a lot of virtuosic improvisational passages, added tones to the standard melodic configuration for this song, and with relatively frequent use of ornaments, especially acciaccaturas, pralltrillers, mordents, and combinations thereof. Papich's timbre is sharper, which is also a feature of the mentioned Roma trumpeters.

Ivan Kadrich (1990), a Roma trumpeter from eastern Serbia, more precisely from Despotovac. He performed this song at the pre-competition of eastern Serbia trumpet orchestras within the "Crnorechje u pesmi i igri" event in Boljevac. He, like Ivan Papich, performed much more freely, with a lot of virtuosic improvisational passages, added tones to the standard melodic configuration for this song, and with very frequent use of ornaments, especially acciaccaturas, pralltrillers, mordents, and combinations thereof. His articulation was generally sharper, predominantly non legato, performed by tongue striking on the consonant between D and T. Kadrich's timbre is sharper. In general, the interpretation was primarily modeled after Sasha Krstich's frequent use of virtuosic passages, but also Nenad Mladenovich, Miroslav Matushich, and Svetozar Lazovich Gongo.

${ }^{34}$ Trumpet orchestra by Janko Jovanovich and Ljubivoje Dikovich - "Psenicice, sitno seme" followed by the Youtube link https://www.youtube.com/watch?v=sFeJBmKu5g4 [Accessed 20.9.2020].

35 Gucha 2014. Prva truba. "Orkestar Nikole Papicha" (Pshenichice, sitno seme) https://www.youtube.com/watch?v=JzvxVw4GHNU [Accessed 20.9.2020].

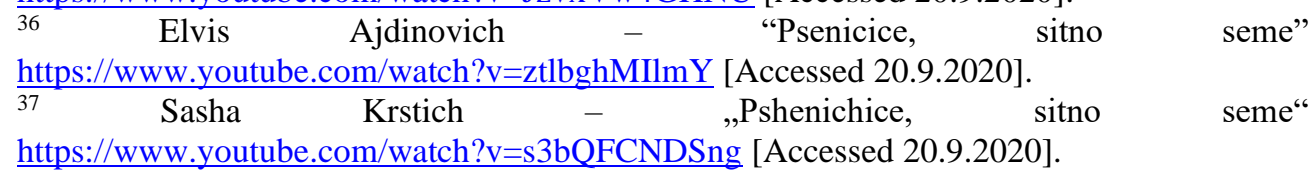


Based on previous theoretical and analytical explications, several key points can be observed in this paper. First, if we look at the exemplary performances of this song, the interpretation by Svetozar Lazovich specifically reflects the hybridity brought by multicultural networking with Miroslav Matushich, though one-way. All the above elements from the analysis represent a synthesis of the West Serbian trumpet style, certain Matushich's stylistic references, and Lazovich's individual trumpeting characteristics. On the other hand, Boban Markovich's performance has a more personal interpretation, which can also be seen as a general stylistic feature of trumpeting in southeastern Serbia.

Most of today's younger trumpeters in western Serbia mainly rely on the interpretation of Svetozar Lazovich Gongo, though relying on performances of Roma trumpeters, such as Boban Markovich, Nenad Mladenovich or Sasha Krstich are not uncommon either. They mostly take virtuosic passages and variations of the standard melodic line from the mentioned Roma trumpeters. Of ornaments, they predominantly use pralltrillers, mordents, acciaccaturas, and combinations thereof, as well as a trill in a characteristic place. The most common articulation is non legato, which can be softer or harder, and legato. This also, to some extent, influences the timbre, which depends on the role model, but also on the personal performance style.

Based on everything that has been said so far, it can be concluded that the song "Pshenichice, sitno seme" is a significant example of a hybrid acceptance of diversity in terms of style and performance. Symbolically, this song is one of the examples that illuminate the path to further musical and cultural non-discrimination in a multiethnic and multicultural society.

\section{LITERATURE}

\section{CYRILIC}

БАБИЋ, Д. (2004). Прича о српској труби. Београд: Београдска књига.

МАЦИЈЕВСКИ, И. (2014). „Извођачка природа и уметнички текст у етничкој музици“. Музикологија, год. II, бр. 17, 17-18.

ЗАКИЋ, М., Лајић Михајловић, Д. (2014). „Међународно такмичење брас-оркестара на Драгачевском сабору трубача у Гучи“. Маринковић, С., С. Додик и А. Петров (ур.). Владо С. Милошевић: етномузиколог, композитор и педагог, Традиција као инспираџија, Тематски зборник. Бања Лука: Академија умјетности Универзитета у Бањој Луци, Академија наука и умјетности Републике.

ПРЕЛИЋ, М. (2012). „Мултикултурализам: расправа која траје“. Зборник Матице српске за друштвене науке, бр. 139, 140-141.

СТОЈИЋ, Н., Ј. Лукић, Н. Бојовић, Ј. Славковић и М. Петровић. (2007). Трубачка будилища: од Гуче до вечности. Чачак: ТВ „Галаксија 32”. Гуча: Радио „Драгачево”. 


\section{LATIN}

DESROCHES, M. (2008). "Entre texte et performance: l'art de raconteur". Cahiers d'ethnomusicologie, no. 21, 103-115.

KELNER, D. (2004). Medijska kultura. Studije kulture, identitet i politika izmedzu modernizma i postmodernizma. Beograd: Clio.

LAJICH MIHAJLOVICH, D., Zakich, M. (2012). "Dragacevo Trumpet Festival in Guca - a place of networking music cultures". Зборник Матице српске за друштвене науке, бр. 139, 223-236.

LAJICH MIHAJLOVICH, D. (2013). "The Dragacevo Trumpet Festival in Guca, Serbia. Musical Spectacle - Brass Bands` Midnight concert. Gisa Jachnichen (ed) Studia instrumentorum musicae popularis, br. III, 18-31.

LORTAT-JACOB, B. (1987). L'improvisation dans les musiques de tradition orale. Paris: SELAF.

LUNDBERG, D, MALM K., RONSTRÖM O. (2003). Music, Media, Multiculture: Changing Musicscapes. Stockholm: Svenskt Visarkiv.

OBER, L. (2007). Muzika drugih: novi izazovi etnomuzikologije. Beograd: Biblioteka XX vek.

RICE, T. (2007). "Reflections on music and identity in Ethnomusicology". Музикологија, год. I, бр. 7, 22-24.

RICE, T. (2010). "Ethnomusicological theory". Yearbook for Traditional Music, vol. 42, 109.

TIMOTIJEVICH, M. (2005). Karneval u Guchi: Sabor trubacha 1961-2004. Chachak: Legenda.

ZAKICH, M, Lajich Mihajlovich, D. (2012). "(Re)creating the (folk music) tradition: the national competition of brass orchestras at the Dragachevo trumpet festival". New Sound, god. I, br. 39, 58-79.

\section{SITEOGRAPHY}

"Pshenichice, sitno seme" https://www.youtube.com/watch?v=j$\underline{\text { Aiz9OZUC4 }}$

Boban

Markovich

"Psenicice

sitno

seme"

https://www.youtube.com/watch?v=13XcHd5W4RY

Boban Markovich https://sr.wikipedia.org/wiki/Boban Markovic

Dzambo Agushevi Orchestra (Macedonija) - Gucha 2011 - International Contest https://www.youtube.com/watch?v=Lyvq9mDtgNI

Elvis Ajdinovich - "Pshenichice, sitno seme" https://www.youtube.com/watch?v=ztlbghMIlmY

https://sr.wikipedia.org/sr-ec/Србија\#Народи_ и националне мањине

https://www.coe.int/t/dg4/intercultural/Source/Pub_White_Paper/WhitePaper

_ID_SerbianVersion.pdf

Jovica Petkovich - "Psenicice sitno sjeme" https://www.youtube.com/watch?v=bwmS9bAwNB8

Junuz Ismailovich - $\quad$ "Klisursko kolo"

https://www.youtube.com/watch?v=usrLvzXeiBU 
Junuz

Ismailovich

"Vrlolecko

kolo"

https://www.youtube.com/watch?v=8WvqqlE9Ons

Ljubisha Pavkovich - "Psenicice sitno sjeme"

https://www.youtube.com/watch?v=SKX8YclAT9Y

Milovan Micha Petrovich \& Osman i Slobodan Salijevich 1993 https://www.youtube.com/watch?v=5N4cL0Bj-p4

Miroslav Matushich - "Psenicice sitno sjeme"

https://www.youtube.com/watch?v=xFkGkdAXaXQ

Nenad Mladenovich - "Pshenichice, sitno seme" 1986

https://www.facebook.com/goran.antesevic/videos/10213472036064194

Orchestar by Janko Jovanovich and Ljubivoje Dikovich - "Psenicice sitno seme" https://www.youtube.com/watch?v=sFeJBmKu5g4

Orchestar by Nikola Papich - "Pshenichice, sitno seme" https://www.youtube.com/watch?v=JzvxVw4GHNU

Predrag Cune Gojkovich - "Psenicice sitno sjeme (Audio 1965)" https://www.youtube.com/watch?v=93GC-IhoDmo

Radojka Zhivkovich - "Psenicice sitno sjeme" https://www.youtube.com/watch?v=OeeJhrLOqHw

Sasha Krstich - "Pshenichice, sitno seme"

https://www.youtube.com/watch?v=s3bQFCNDSng

Svetozar Lazovich Gongo - "Draganovo kolo"

https://www.youtube.com/watch?v=O0rcenhvpbQ

Svetozar Lazovich Gongo - "Psenicice sitno sjeme"

https://www.youtube.com/watch?v=GixOzfvU7ME

Trumpet orchestra by Junuz Ismailovich - "Dragachevka" https://www.youtube.com/watch?v=sNOAl-d3Ayo

Trumpet orchestra by Veljko Ostojich - "Pshenichice, sitno seme" https://www.youtube.com/watch?v=qwL2grjVPn0

Јелена Јоковиќ

\section{ИНТЕРСТИЛСКО ВМРЕЖУВАЊЕ НА ТРУБАЧКИТЕ ОРКЕСТРИ ВО: ЗАПАДНА, СЕВЕРОИСТОЧНА И ЈУГОИСТОЧНА СРБИЈА, СПОРЕД ПРИМЕРОТ НА ИЗВЕДУВАЊЕ НА МЕЛОДИЈАТА НА ПЕСНАТА „ПШЕНИЧИЦЕ, СИТНО СЕМЕ“}

Резиме

Современото трубаштво на Србија, во поглед на репертоарот, е многу хетерогено и хибридно. Трубачките оркестри, покрај нумерите (мелодиите на народните песни и ора/чочеци), кои потекнуваат од крајот од каде што доаѓаат, изведуваат и репертоар од другите трубачки стилови од Србија. Овој труд се занимава со мултиетничките интерстилски вмрежувања и индивидуалните изведувачки карактеристики на трубачите, по примерот на изведување на песната „Пшеничице ситно семе“" и улогата на различните мелодии низ нејзината трансмисија. Оваа песна е една од доста популарните песни во светот на трубачката музика во Србија, но, со текот на времето, ги надминала своите граници. Прв ја снимил (1972 година) 
влашкиот свирач со ромско потекло Мирослав Матушиќ (1925 - 1991) од Кучево. Често се изведува на Драгачевскиот собир на трубачи во Гуча, на националното и на меѓународното натпреварување, како во сениорска, така и во младинска конкуренција. На Собирот прв пат се слушнала во 1980 година, а потоа станала позната во цела западна Србија, благодарение на трубачот Светозар Лазовиќ-Гонго $(1951$ - 2001) од Дражиновиќи кај Пожега. Оваа песна ја изведувале и трубачки оркестри од југоисточна Србија, како што се: Ненад Младеновиќ (1970), Бобан Марковиќ (1964) и други. Врз основа на етномузиколошките компаративни анализи на транскрипцијата и на аудиоснимката, во интерпретацијата на Светозар Лазовиќ се забележува синтеза на западносрпските трубачки стилови, како и отсликување на стилските реферации и индивидуалните трубачки карактеристики на Матушиќ. Од друга страна, изведбата на Бобан Марковиќ, во која тој дава послободна интерпретација во поглед на: виртуозната импровизација, пасажот и хроматските тонови, може да се набљудува како главна стилска особина на трубаштвото во југоисточна Србија. Многу од денешните млади трубачи од западна Србија, најчесто се потпираат на интерпретацијата на Светозар Лазовиќ-Гонго, но не се ретки и реферациите од ромските изведувачи на труба, како што се: Бобан Марковиќ, Ненад Младеновиќ или Саша Крстиќ (1982). Од наведените ромски трубачи најчесто ги преземаат виртуозните пасажи и најразличните варирања на стандардната мелодиска линија. Од украсите најчесто користат пралтрилери, морденте, предудари и нивни комбинации, како и трилери на карактеристични места. Најчеста артикулација е non legato, која може да биде помеко или потврдо изведена, и legato. Под тоа влијание, донекаде, е и изведувачкиот тембр, кој зависи од примарниот, но и од личниот изведувачки стил. На крајот може да се заклучи дека песната „Пшеничице ситно семе“ претставува значаен пример на хибридно прифаќае на различностите во стилскоизведувачки поглед. 




$\mathrm{g}^{2} \mathrm{~b}_{\mathrm{B}}$

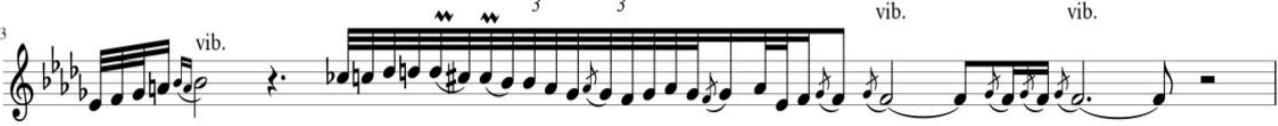
$g^{4} b_{0}$ w

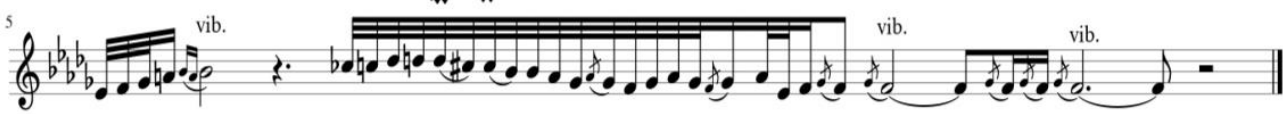
Example no. 1

$\frac{6}{3}$

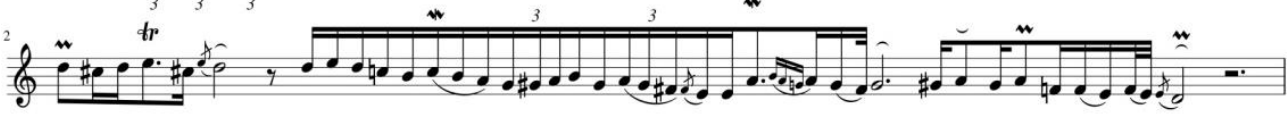

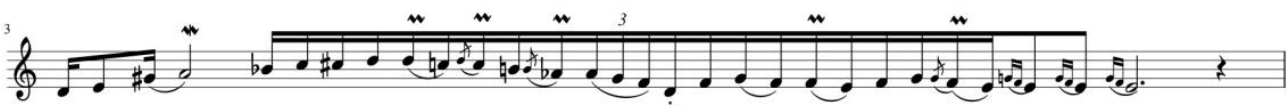

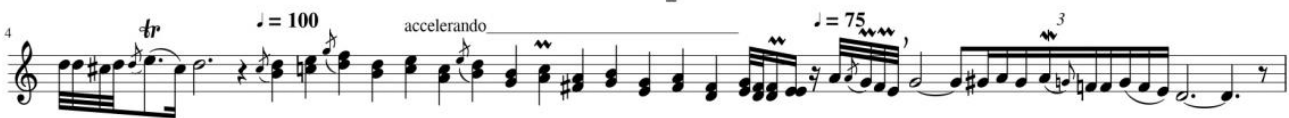


Example no. 2 
Flugelhorn $1 \mathrm{C}_{b}{ }_{b}$ Flghn. $1 \oint_{b_{b}^{b} b_{b}}^{2}$



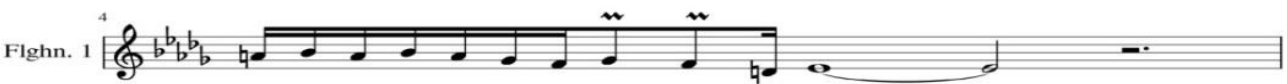

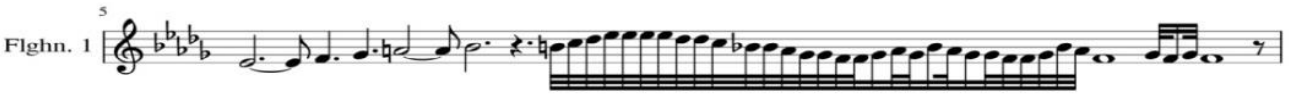
Flghn. $1 \oint_{b_{b}^{b} b_{b}}$

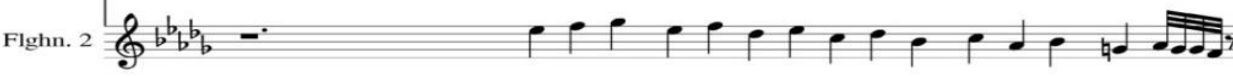



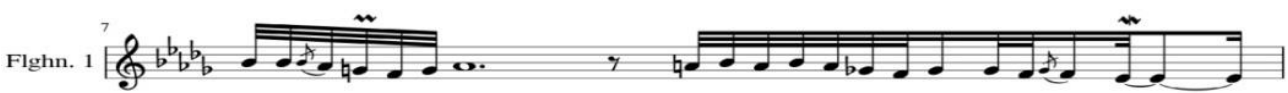
Flghn. $1 \oint^{8} b_{b} b^{2}$.

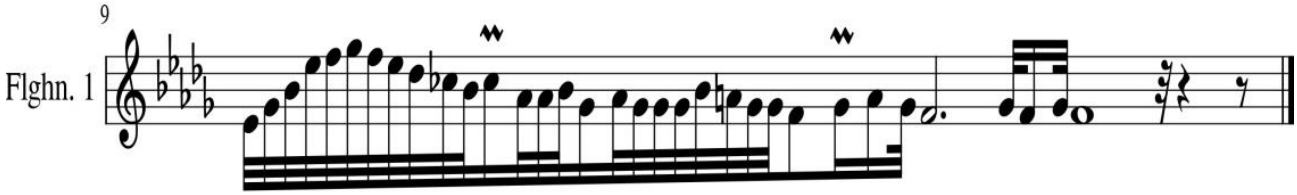
Example no. 3 